\title{
News from the Seventeenth Century
}

\author{
Robert Ferrari, MD, FRCPC, FACP \\ Room 4000, Research Transition Facility, University of Alberta, Edmonton, Alberta, Canada.
}

J Gen Intern Med 25(10): 1134

DOI: $10.1007 / \mathrm{s} 11606-010-1397-7$

(c) Society of General Internal Medicine 2010

$\mathrm{C}$

ome, I'll sing upon his breath,

Or hold his lungs for scanners till they smile and burst

Out the answer before the question,

The lesson before the problem first.

Today, I am a virus, I come,

From the ages of pathogens. I am but one

More voice added to the message,

Sent through the socialized body, that none

Like truth, like lies, realize the media is dead.

Pick a pocket, pick a person, spot another who learns

To doubt the response before the challenge,

As I, unyielding, continuously return.

I was phobic for a time. Yes. I hid within the earth.

The earth! What marvelous days they proved,

For years and days and hours I danced,

Alone, ungathered, before our togetherness joined

Again, again, the bodies, we counted and chanted.

After years (and days and hours) in the dark,

At first curled in worms and caseous limb,

I urged myself out the mounds of rodent fur

And plagued, each one and one, till I could swim,

Through every far ocean: drowned the rats,

Swam to Spain and Panama; and Africa learned,

That a virus could beat the drums again.

Or, when people breathed easy, I became a bird.

A publicly gray bird, I whistled your vaccines.

For H1N1: a new prophet blurts,

And speaks about the cure before the sore,

An answer, and not the problem first.

Published online May 22, 2010 